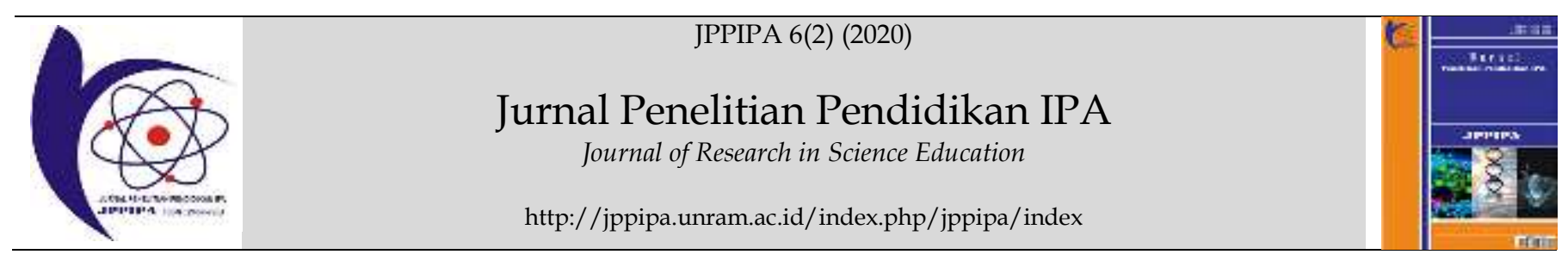

\title{
Science Literacy Ability of Elementary Students Through Nature of Science-based Learning with the Utilization of the Ministry of Education and Culture's "Learning House"
}

\author{
Hana Lestari ${ }^{1^{*}}$, Wawan Setiawan², Ridwan Siskandar ${ }^{*}$ \\ ${ }^{1}$ Faculty of Teacher Training and Education, Sahid Entrepreneurial University, Bogor, Indonesia \\ ${ }^{3}$ Computer Science Education Program, Universitas Pendidikan Indonesia, Bandung, Indonesia \\ ${ }^{2}$ Computer Engineering Study Program, Collage of Vocational Studies, IPB University, Bogor, Indonesia.
}

\section{DOI: $10.29303 /$ ippipa.v6i2.410}

\section{Article Info}

Received: March 12th, 2020

Revised: June $25^{\text {th }}, 2020$

Accepted: July $8^{\text {th }}, 2020$

\begin{abstract}
Students' scientific literacy skills can be developed and enhanced with appropriate learning models and supported by adequate technology. This study aims to determine the improvement of the science literacy skills of elementary students through the Nature of Science learning model by utilizing the "Learning house" feature of the Ministry of Education and Culture. The research method used was a pre-experiment with one group pretest-posttest design. The instrument used was in the form of a science literacy ability test and an observation sheet of learning implementation with the research subjects of 38 students of Cibatok I Elementary School, Bogor, West Java, VA, and VB classes in 2018/2019 school year. The data obtained were analyzed by the Wilcoxon test using SPSS 22 at a (0.05). The results showed that (1) there was an increase in students' scientific literacy skills through the Nature of Science learning model by utilizing the "Learning house" feature of the Ministry of Education and Culture, this was indicated by $\operatorname{sig}(0,000)<a(0.05)$; (2) The average scientific literacy ability of students after being given the Nature of Science learning model by utilizing the "Learning house" feature of the Ministry of Education and Culture (3.75) is higher than the average scientific literacy ability of students before being given the Nature of Science learning model by utilizing the Ministry of Education and Culture's "Learning house" feature (2.57). It can be concluded that the Nature of Science learning model by utilizing the "Learning house" feature of the Ministry of Education and Culture can significantly increase the level of students' scientific literacy abilities.
\end{abstract}

Keywords: Science Literacy; Nature of Science Learning Model; "Learning House" feature of the Ministry of Education and Culture.

Citation: Lestari, H., Setiawan, W., \& Sikandar, R. (2020). Science Literacy Ability of Elementary Students Through Nature of Science-based Learning with the Utilization of the Ministry of Education and Culture's "Learning house". Jurnal Penelitian Pendidikan IPA (JPPIPA), 6(2), 215-220. doi: https://doi.org/10.29303/jppipa.v6i2.410

\section{Introduction}

Entering the 21st century, the progress of science and technology is developing rapidly marked by the industrial revolution 4.0. Industrial revolution 4.0 is a change in the industrial world marked by manufacturing activities integrated with digital technology and big data on a massive scale. Basically, the industrial world is always side by side with the

Email: hanabiologi@gmail.com ; ridwansiskandar@apps.ipb.ac.id 
world of education. The world of education currently utilizes various technologies in helping the learning process in schools (Law Nancy et al., 2018).

The existence of the 4.0 Industrial Revolution directed the educational process to give birth to generations who are "literate in science and technology". Science itself is the science of understanding the universe by using scientific methods regarding events in the universe (Mccomas \& Olson, 2002). The presence of science builds one's character and behavior by forming a mindset to care for and be responsible for oneself, society, and the universe that is defined as scientific literacy (Lestari \& Rahmawati, 2020a).

Science literacy is a science and understanding of scientific concepts and processes that enable a person to make a decision with the knowledge he has and is able to play an active role in all aspects of life, especially in the field of science he is engaged in (Jack Holbrook, 2009). Science literacy can be interpreted as an understanding of science and its processes, as well as its application to the needs of society (Jamaluddin et al., 2019), then the ability of scientific literacy can be explained as the ability to solve problems and make decisions with the knowledge they have in accordance with their level and are able to utilize the technology around it (Gormally et al., 2012; Lestari et al., 2019).

Based on this understanding, the emphasis on the ability of scientific literacy is not on mastering knowledge and understanding of science concepts and processes, but rather directing how to enable someone to be able to make a decision and be involved in community life, based on their knowledge and understanding of science (Hasasiyah et al ., 2019; Huryah et al., 2017). A society that is objective, processable, and has good scientific ability will produce skilled experts, scientists, engineers, and professors who are able to improve the country's economy (Windyariani, 2018). Therefore, as a large nation, Indonesia must be able to develop a culture of scientific literacy through integrated education, ranging from families, schools, to the community.

At the level of school education, scientific literacy skills need to be developed early on from elementary school age, students' knowledge and understanding of science related to science content, science products, and scientific work processes (Yuliati, 2017). According to (Gormally et al., 2012) indicators of scientific literacy include identifying valid scientific opinions, conducting effective literature searches, understanding elements of research design, making precise charts of data, solving problems using quantitative skills, including basic statistics, understand and interpret basic statistics, and make inferences, predictions, and conclusions based on quantitative data.
At the primary school level, the development of students' scientific literacy skills can be developed in the science learning process in schools through a variety of guided inquiry-based teaching materials (Komalasari et al., 2019). But besides being able to be developed with teaching materials used by teachers, students' scientific literacy skills can be improved through appropriate learning models (Lestari \& Siskandar, 2020).

One learning model that can be applied in order to improve students' scientific literacy skills is the Nature of Science (NoS) based learning model (Lestari \& Rahmawati, 2020b). NoS as a basic science that must be understood and studied well because it emphasizes direct giving to develop competencies in order to explore and understand the natural environment scientifically in practicing scientific literacy skills (Abd. Khalick, Randy.L, Bell, 1998).

The NoS learning model makes students understand that scientific knowledge is created from a creative process, scientific knowledge is built and developed based on empirical data (evidence) obtained from experiments with scientific methods, scientific knowledge is tentative can change with the existence of new evidence, scientific knowledge is influenced by personal subjectivity, scientific knowledge can be in the form of law or in the form of theories that are influenced by the social and cultural community (Hacieminoglu, 2014, 2016; McComas \& Nouri, 2016; Mccomas \& Olson, 2002).

In Indonesia, research on NoS is starting to develop, information on NoS understanding of primary school students, elementary school teachers, and prospective elementary school teachers have been studied. Based on the results of the study the understanding of prospective teachers and elementary school teachers regarding NoS in both categories and the understanding of NoS students and elementary school teachers are still in the sufficient category (Adi \& Widodo, 2018; Jumanto \& Widodo, 2018; Lestari \& Rahmawati, 2020b). Thus, the NoS-based learning model can be implemented in order to develop students' scientific literacy abilities.

In addition to the right learning model, adequate technology support is needed in order to develop scientific literacy skills. Today's digital technology makes it easy for educational elements both teachers and students can utilize various digital learning content to facilitate the learning process (Lestari et al., 2020). In the era of digitalization, digital content is widely used in education in order to improve the quality of learning in the classroom. Digital content in the realm of learning is implemented through digital learning media that contains teaching material that is packaged and delivered through various digital media such as blogs, websites, podcasts to other social media (Karabegović, 
2017). Digital content can be used as an attractive learning media for students and facilitate learning models that are applied in the classroom, so learning can run optimally because in a learning process there are two important elements that can affect the efficiency, effectiveness, and learning outcomes of learning models and learning media.

The ability of students' scientific literacy through the NoS-based learning model can be developed by utilizing digital science content as a learning medium. One digital science content that can be accessed and utilized by teachers and students is the home learning site developed by the Ministry of Education and Culture (https:// belajar.kemdikbud.go.id/).

The learning house is a learning portal that provides learning materials and communication facilities that support interaction between communities. Learning house is present as a form of learning innovation in the industrial era 4.0 that can be utilized by students and teachers of Early Childhood Education, Elementary Schools, Junior High Schools, Senior High Schools/Vocational Schools, and their equivalents. By using the Learning House, we can study anywhere, anytime with anyone. All content in a Learning house can be accessed and utilized free of charge.

The learning house portal has four main features namely digital classes, learning resources, virtual laboratories, and question banks. Digital class features in the form of a learning management system (LMS) that was developed specifically to facilitate the process of virtual learning or no face-to-face between teachers and students. With this feature, the teacher can provide teaching materials that can be accessed and shared by students in digital form anytime and anywhere. The learning resource feature presents teaching material for students and teachers based on the curriculum. Teaching material is presented in a structured manner with an attractive appearance in the form of images, videos, animations, simulations, evaluations, and games. Virtual laboratory features in the form of laboratory lab simulations are presented interactively and attractively. Whereas the question bank feature is a feature collection of student questions and evaluation material grouped by teaching topics. There is also various access to practice questions, tests, and exams.

Stages of the NoS-based learning model by utilizing the "home learning" feature used in this study can be explained as follows (1) reviewing and exploring theories and laws that have been understood by students subjectively to be stimulated through various digital content of learning, (2) looking for creative and empirical new evidence to formulate new knowledge with scientific methods such as those done by scientists through experimental activities, (3) developing new knowledge that is tentative proven by empirical evidence based on experimental results in the laboratory (4) validating new knowledge that is tentative based on the results of experiments, and comparing the results of experiments in the laboratory, and comparing with the results of experiments using virtual laboratories (5) synthesizing new knowledge gained to solve problems related to socio, cultural embeddedness creatively.

\section{Method}

The research method used was a pre-experiment with one group pretest-posttest design. The instrument used was in the form of a science literacy ability test and an observation sheet of learning implementation with the research subjects of 38 students of Cibatok I Elementary School, Bogor, West Java, class VA, and VB in the academic year 2018/2019. The scientific literacy test instrument in this study was in the form of multiplechoice questions totaling 20 questions with indicators developed by Gormally (2012). The scientific literacy test instrument is then tested in a contractual and empirical validation and is tested for reliability by alignment testing. The indicators of scientific literacy can be explained in Table 1.

\begin{tabular}{|c|c|}
\hline No & Indicator \\
\hline 1. & Identifying valid scientific opinions \\
\hline 2. & Carry out effective literature searches \\
\hline 3. & Understand the elements in research design \\
\hline 4. & Make a precise graph of the data \\
\hline 5. & $\begin{array}{l}\text { Solve problems using quantitative skills, including } \\
\text { basic statistics }\end{array}$ \\
\hline 6. & Understand and interpret basic statistics \\
\hline 7. & $\begin{array}{l}\text { Inference, prediction and conclusion based on } \\
\text { quantitative data }\end{array}$ \\
\hline
\end{tabular}

The data obtained were then analyzed descriptively and inferentially (Wilcoxon test) using software spss 22 at a $=0.05$, to determine differences in students' scientific literacy abilities before and after NoS learning by utilizing the "home learning" feature.

\section{Result and Discussion}

The data were analyzed statistically descriptive, and the average data obtained from students' scientific literacy skills, before and after the NoS learning model by utilizing the "Learning House" feature can be seen in Figure 1. 
Science Literacy ability of students in each indicator (\%)

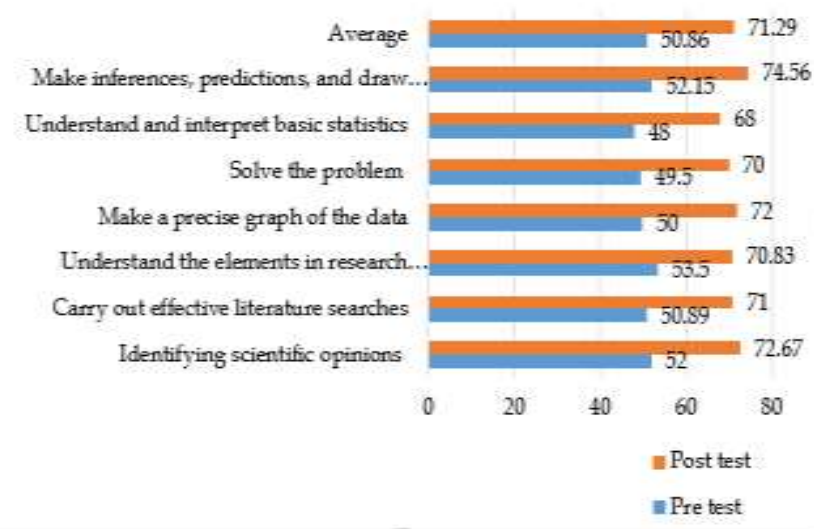

Figure 1. Average Student's Literacy Ability Score for Each Indicator

Figure 1 shows that there is an increase in students' literacy skills between before and after NoS learning by utilizing the "Learning house" feature. Before giving the NoS learning model, the average scientific literacy ability of students was 50.86 , while after giving the NoS learning model 71.29. So, it can be concluded that there are differences in students 'scientific literacy abilities before and after the provision of the NoS learning model by utilizing the "home learning" feature, meaning that the NoS learning model by utilizing the "Learning house" feature affects the increase in students' scientific literacy abilities. To determine whether there is a significant difference in students' scientific literacy skills before and after the provision of the NoS learning model by utilizing the "home learning" feature, the data were tested with Wilcoxon using SPSS 22 software at a (0.05), and the following output was obtained:

Tabel 2. Wilcoxon Test Results

\begin{tabular}{llll}
\hline & N & Mean & Sig (2-Tailed) \\
\hline Pretest & 38 & 50.67 & 0.000 \\
Posttest & 38 & 72.33 & \\
\hline
\end{tabular}

Table 2 shows that the sig value of 0.007 is smaller a (0.05), meaning that the scientific literacy ability of students can be improved through the NoS learning model by utilizing the "Learning house" feature. This can be explained that the scientific literacy ability of students after giving the NoS learning model by utilizing the "home learning" feature can be improved on each indicator, and can be explained as follows: in indicator 1 namely identifying valid scientific opinions, from an average value of 52 experienced an increase to 72.67 and indicator 2 namely effective literature search, from an average value of 50.89 increased to 71.00 Students' scientific literacy abilities on indicators 1 and
2 can be improved through NoS learning by utilizing the "home learning" feature, through the stages of reviewing and re-exploring theories and laws that have been understood by students subjectively by stimulating through various digital content of learning, students understand that scientific knowledge is a law that describes relationships, observations about natural events, and scientific knowledge contains theories that explain natural events and mechanisms e relationship between these natural events, thus training students to be able to think critically and differentiate scientific opinions, in this case students are able to review scientific research, data, and research results to contain decisions about problems that often arise related to science (Lestari \& Siskandar, 2020).

In indicator 3 namely understanding the elements in the research design from an average value of 53.5 has increased to 70.83 and the fourth indicator that is making a precise graph of the data has increased from 50 to 72 . Students' scientific literacy ability in indicators 3 and 4 can be improved through NoS learning by utilizing the "home learning" feature through the stages of searching for new evidence creatively and empirically to formulate new knowledge with scientific methods as practiced by scientists through experimental activities. Before students conduct experiments first students make experimental designs such as research variables and hypotheses.

The making of experimental design can be assisted by the learning resource feature on the "learning house" portal, a complete learning resource feature accompanied by learning videos and animations related to the experimental design. The indicator aspects of making charts from the data are trained by means of experimental activities carried out by students. Through these experiments, students are trained to make a graph of the results of experiments conducted in order to search for new evidence creatively and empirically. How to graph the correct data can be exemplified by the teacher as a facilitator through the virtual laboratory features in the portal "home learning". Graphs in scientific literacy can be understood by students by interpreting certain data by making graphs of various types of graphs based on their usefulness and data graphs are a form of scientific claims in supporting quantitative data in scientific literacy (Gormally et al., 2012; Rahmadani et al., 2018 ).

In indicator 5 namely solving problems using quantitative skills, including basic statistics from an average score of 49.5 has increased to 70 . The ability of students' scientific literacy in indicator 5 can be improved through NoS learning by utilizing the "home learning" feature through the stages of developing new knowledge which is tentative proven by empirical evidence. At this stage, students solve quantitative 
problems from the results of graphs and statistical calculations performed in experiments.

The 6th indicator that is understanding and interpreting basic statistics has increased from 48 to 68 . The scientific literacy ability of students in indicator 6 can be improved through NoS learning by utilizing the "home learning" feature through the stages of validating tentative new knowledge based on experimental results, and comparing the results experiments in the laboratory, and compare with the results of experiments using a virtual laboratory in the portal "home of learning". At this stage, students are trained to validate the results of experiments conducted and compare them with the results of experiments using virtual laboratories.

The 7th indicator which is inference, prediction, and conclusion based on quantitative data has increased from 52.15 to 74.56 . The ability of students' scientific literacy on indicator 7 can be improved through NoS learning by utilizing the "home learning" feature through the stages of synthesizing new knowledge. At this stage, students are trained to make conclusions from the results of the experiment.

The NoS learning model facilitates students in developing scientific literacy skills by enabling students to understand the background to the formation and development of science by learning how science and scientists work, how scientific knowledge is created, validated, and influenced (McComas \& Nouri, 2016; Mccomas \& Olson, 2002); how to study the way scientists formulate knowledge (Abd. Khalick et al., 1998; Lederman et al., 2002); and as a way to find out the characteristics of the development of scientific knowledge itself (Mercado et al., 2015).

The NoS learning model is even more effective with the help of the use of the "home learning" feature as a learning medium at every stage of the NoS learning model. The use of the "home learning" feature stimulates students to be motivated in learning, through the use of learning videos, learning animations and virtual laboratories that facilitate students in the learning process and understand each content of teaching material.

\section{Conclusion}

It can be concluded that the Nature of Science learning model by utilizing the "Learning house" feature of the Ministry of Education and Culture can significantly increase the level of students' scientific literacy abilities. The results showed: (1) there was an increase in students' scientific literacy skills through the Nature of Science learning model by utilizing the "Learning house" feature of the Ministry of Education and Culture, this was indicated by sig $(0,000)<\alpha(0.05)$;
(2) The average scientific literacy ability of students after being given the Nature of Science learning model by utilizing the "home learning" feature of the Ministry of Education and Culture (3.75) is higher than the average scientific literacy ability of students before learning (2.57).

\section{References}

Abd. Khalick, Randy.L, Bell, N. L. (1998). The nature of science and instructional practice: Making the unnatural natural. Science Education, 82(4), 417-436.

Adi, Y. K., \& Widodo, A. (2018). Pemahaman Hakikat Sains Pada Guru Dan Siswa Sekolah Dasar. Edukasi Journal, 10(1), 55-72. https://doi.org/10.31603/edukasi.v10i1.1831

Gormally, C., Brickman, P., \& Lut, M. (2012). Developing a test of scientific literacy skills (TOSLS): Measuring undergraduates' evaluation of scientific information and arguments. CBE Life Sciences Education, 11(4), 364-377. https://doi.org/10.1187/cbe.12-03-0026

Hacieminoglu, E. (2014). In-service Teachers' Perceptions Regarding their Practices Related to Integrating Nature of Science: Case Study. Procedia - Social and Behavioral Sciences, 116(1988), 12681273.

https://doi.org/10.1016/j.sbspro.2014.01.381

Hacieminoglu, E. (2016). Elementary school students' attitudes toward science and related variables. International Journal of Environmental and Science Education, 11(2), 35-52. https://doi.org/10.12973/ijese.2016.288a

Hasasiyah, S. H., Hutomo, B. A., Subali, B., \& Marwoto, P. (2019). Analisis Kemampuan Literasi Sains Siswa SMP pada Materi Sirkulasi Darah. Jurnal Penelitian Pendidikan IPA, 6(1), 5. https://doi.org/10.29303/ippipa.v6i1.193

Huryah, F., Sumarmin, R., \& Effendi, J. (2017). Analisis Capaian Literasi Sains Biologi Siswa Sma Kelas X Sekota Padang. Jurnal Eksakta Pendidikan (Jep), 1(2), 72. https:// doi.org/10.24036/jep.v1i2.70

Jack Holbrook, M. R. (2009). The Nature of Science Education for enhancing Scientific Literacy. International Journal of Science Education, 12, 15371546. https://doi.org/10.1080/09500690601007549 Jamaluddin, J., Jufri, A. W., Ramdani, A., \& Azizah, A. (2019). Profil Literasi Sains Dan Keterampilan Berpikir Kritis Pendidik Ipa Smp. Jurnal Penelitian Pendidikan IPA, 5(1). https://doi.org/10.29303/jppipa.v5i1.185

Jumanto, \& Widodo, A. (2018). Pemahaman Hakikat Sains Oleh Siswa Dan Guru Sd Understanding the Nature of Science By Students and Elementary School Teachers in the City of. Jurnal Komunikasi 
Pendidikan, 2, 20-31.

Karabegović, I. (2017). Digital Technology as the Key Factor in the Fourth Industrial Revolution Industry 4. 0. International Journal of Engineering and Advanced Research Technology (IJEART), 3(3), 17-22.

Komalasari, B. S., Jufri, A. W., \& Santoso, D. (2019). Pengembangan Bahan Ajar IPA Berbasis Inkuiri Terbimbing untuk Meningkatkan Literasi Sains. Jurnal Penelitian Pendidikan IPA, 5(2), 219. https://doi.org/10.29303/ippipa.v5i2.279

Law Nancy, Woo David, de la Torre Jimmy, W. G. (2018). A Global Framework of Reference on Digital Literacy for Indicator 4.42. Educational Technology Research and Development, UIS/2018/ICT/IP/51, 1-144.

Lederman, N. G., Abd-El-Khalick, F., Bell, R. L., \& Schwartz, R. S. (2002). Views of Nature of Science Questionnaire: Toward Valid and Meaningful Assessment of Learners' Conceptions of Nature of Science. Journal of Research in Science Teaching, 39(6), 497-521. https://doi.org/10.1002/tea.10034

Lestari, H., Banila, L., \& Siskandar, R. (2019). Kemandirian Belajar Melalui Pembelajaran Berbasis Stem Improving Student ' S Science Literacy Competencies Based On Learning Independence With Stem Learning. 14(2), 18-23. http://dx.doi.org/10.30870/biodidaktika.v14i2.61 $\underline{34}$

Lestari, H., \& Rahmawati, I. (2020a). Integrated STEM through Project-Based Learning and Guided Inquiry on Scientific Literacy Abilities in Terms of Self-Efficacy Levels. 7, 19-32.

Lestari, H., \& Rahmawati, I. (2020b). Pemahaman Nos Peserta Didik Sekolah Dasar Hana. Indonesian Journal of Science and Education, 1(1), 18-26. https://doi.org/10.31002/ijose.v2i1.598

Lestari, H., \& Siskandar, R. (2020). Literasi Sains Siswa Melalui Penerapan Model Pembelajaran Blended Learning Dengan Blog. NATURALISTIC: Jurnal Kajian Penelitian Pendidikan, 4(2), 597-604. https://journal.umtas.ac.id/index.php/naturalist ic/article/view/769

Lestari, H., Siskandar, R., \& Rahmawati, I. (2020). Digital Literacy Skills of Teachers in Elementary School in The Revolution 4.0. International Conference on Elementary Education, 2(1), 302-311.

McComas, W. F., \& Nouri, N. (2016). The Nature of Science and the Next Generation Science Standards: Analysis and Critique. Journal of Science Teacher Education, 27(5), 555-576. https://doi.org/10.1007/s10972-016-9474-3

Mccomas, W. F., \& Olson, J. K. (2002). The Nature of Science in Science Education. The Nature of Science in Science Education, December 2014. https://doi.org/10.1007/0-306-47215-5
Mercado, C. T., Macayana, F. B., \& Urbiztondo, L. G. (2015). Examining Education Students ' Nature of Science ( NOS ) Views. Asia Pacific Journal of Multidisciplinary Research, 3(5), 101-110.

Rahmadani, Y., Fitakurahmah, N., Fungky, N., Prihatin, R., Majid, Q., \& Prayitno, B. A. (2018). Profil Keterampilan Literasi Sains Siswa di Salah Satu Sekolah Swasta di Karanganyar. Jurnal Pendidikan Biologi, 7(3), 183. https://doi.org/10.24114/jpb.v7i3.10123

Windyariani, S. (2018). Kemampuan Literasi Sains Siswa Sd Pada Konteks Melestarikan Capung. Biosfer: Jurnal Pendidikan Biologi, 10(1), 17-21. https://doi.org/10.21009/biosferjpb.10-1.3

Yuliati, Y. (2017). Literasi Sains Dalam Pembelajaran IPA. Jurnal Cakrawala Pendas, 3(2), 21-28. https://doi.org/10.31949/jcp.v3i2.592 